\title{
Evaluation of Live Cuttings Effect on Slope Stability
}

\author{
Charles Rodrigo Belmonte Maffra ${ }^{1}$ (D), Rita dos Santos Sousa ${ }^{1}$ (D), \\ Fabrício Jaques Sutili ${ }^{1}$ (D), Rinaldo José Barbosa Pinheiro ${ }^{1}$ \\ ${ }^{1}$ Universidade Federal de Santa Maria - UFSM, Santa Maria/RS, Brasil
}

\begin{abstract}
The aim of this work was to evaluate the development of shrub live cuttings and their effect on slope stability. Vertical in situ pullout tests and measurements of Phyllanthus sellowianus shoots and roots of 2, 4, 6, 8, 10 and 14 months old were conducted. Stability analyses were conducted for slopes with planar and curved rupture surfaces and for soils with and without plants. The results showed that seasons affected plants growth and their ability to provide soil strength. Soil shear strength values ranged from $4.5 \mathrm{kPa}$ ( 2 months old) to $47.6 \mathrm{kPa}$ (14 months old). The critical factors of safety (FS) for slopes for both planar and curved rupture surfaces were found in the absence of plants and reached the stability condition (FS $>2)$ with plants at 4 (planar) and 6 (curved) months old.
\end{abstract}

Keywords: soil bioengineering, ecological restoration, soil-root interaction, factor of safety, soil reinforcement. 


\section{INTRODUCTION}

In recent years the reclamation and stabilization of river banks and slopes through techniques that use plants and other elements easily found in nature (rocks, wood, soil, etc.) as building materials has been gaining prominence (Maffra \& Sutili, 2017; Sousa et al., 2017).

Despite the growing use of plants in engineering interventions, quantitative information on the influence of root system development on slope stability, and on how the effect of these living elements can be added to the safety coefficients of geotechnical interventions are still scarce or non-existent.

Among the main methods used to account for the contribution of plants to soil shear strength, the perpendicular root model (Wu, 1976; Waldron, 1977; Wu et al., 1979) has been the most used model due to its great conceptual simplicity. The model relies on only obtaining two variables, the root rate per soil area and the tensile strength of the roots.

The greatest practical problem of the perpendicular root method is the difficulty in obtaining the in situ root rate per soil area. In the case of plants propagated by vegetative propagation (live cuttings), this difficulty has been circumvented by using vertical pullout tests, which have been used as being indicative of their contribution to soil shear strength (Wu et al., 2014).

In practice, slope stability is evaluated according to the factor of safety, which is the relationship between the resisting forces and the driving forces that act on a soil mass. In general, when the factor of safety value is greater than 1 , the slope is stable; when the factor of safety is equal to 1 , the slope is unstable (limit equilibrium condition); and when the factor of safety is less than 1, there is no physical meaning (Gerscovich, 2016).

For slope stability calculations, plants contribution is usually added to the resisting forces as an addition to soil cohesion (Coppin \& Richards, 2007).

According to the Brazilian Standard of Slope Stability (ABNT, 2009), the adoption of a certain factor of safety depends on the risks involved such as the possibility of human deaths, as well as environmental and material damage or losses. Thus, the prevention of such events is ensured by factor of safety values greater than 1 , so that values greater than 1.5 are considered high, those between 1.3 and 1.5 are considered average, and those between 1.1 and 1.3 are considered low.

In order to contribute to the understanding of plants as engineering materials, the present study aimed to evaluate the effect of live cutting development on slope stability.

\section{MATERIAL AND METHODS}

\subsection{Study site and characteristics of the experiment}

The experiment was carried out in the municipality of São João do Polêsine, Rio Grande do Sul, Brazil ( $29^{\circ} 39^{\prime} 8^{\prime \prime}$ South; $53^{\circ} 31^{\prime} 40^{\prime \prime}$ West). The average annual precipitation in the region is $1600 \mathrm{~mm}$, while the average annual temperature is $19.7^{\circ} \mathrm{C}$. The soil in the study area is of colluvial origin, being characterized as up to $1.0 \mathrm{~m}$ of depth with sand, silt and clay contents of $74.6,17.8$ and $7.6 \%$, respectively. The soil density is $1.43 \mathrm{~g} / \mathrm{cm}^{3}$ and the porosity is $0.45 \mathrm{~m}^{3} / \mathrm{m}^{3}$ (Table 1 ). Due to the predominance of the sand fraction, the soil shear strength is low at about $6.4 \mathrm{kPa}$, and internal friction angle of $27.3^{\circ}$ (ASTM, 2011). Chemically the soil is acidic, and it has an average amount of potassium and low levels of phosphorus, organic matter and aluminum (Table 1).

The area of the experiment is $17 \mathrm{~m}$ long and $7 \mathrm{~m}$ wide. Preparation to receive planting in September 2013 consisted in weed mowing and ant control using a Fipronil-based fomicide. One hundred and forty four (144) cuttings of Phyllanthus sellowianus of $50 \mathrm{~cm}$ in length and $2.5 \mathrm{~cm}$ in diameter were planted in pits of $40 \mathrm{~cm}$ of depth and $15 \mathrm{~cm}$ in diameter, according to a $1 \mathrm{x} 1 \mathrm{~m}$ spacing. The experiment was divided into 6 evaluation periods, each containing 24 cuttings. Temperature and precipitation data were collected monthly. Data on plant growth were collected at $2,4,6,8,10$ and 14 months after planting.

Weed growth in the experiment area was controlled monthly by mowing.

\subsection{Vertical pullout and biometric measurements}

The tests for the tensile strength of the root system were performed in situ using a machine specifically developed for the vertical pullout of plants. 
Table 1. Physical and Chemical characteristics of the soil in the study area.

\begin{tabular}{|c|c|c|c|c|c|c|c|c|c|c|c|}
\hline \multirow{3}{*}{$\begin{array}{c}\text { Depth } \\
(\mathrm{cm})\end{array}$} & \multicolumn{6}{|c|}{ Physical } & \multicolumn{5}{|c|}{ Chemical } \\
\hline & \multicolumn{3}{|c|}{$\begin{array}{c}\text { Granulometry } \\
(\%)\end{array}$} & \multirow{2}{*}{$\begin{array}{c}\text { Soil } \\
\text { density } \\
\left(\mathrm{g} / \mathrm{cm}^{3}\right)\end{array}$} & \multirow{2}{*}{$\begin{array}{l}\text { Particle } \\
\text { density } \\
\left(\mathrm{g} / \mathrm{cm}^{3}\right)\end{array}$} & \multirow{2}{*}{$\begin{array}{l}\text { Porosity } \\
\left(\mathrm{cm}^{3} / \mathrm{cm}^{3}\right)\end{array}$} & \multirow{2}{*}{$\begin{array}{c}\mathbf{P} \\
\left(\mathbf{m g} / \mathbf{d m}^{3}\right)\end{array}$} & \multirow{2}{*}{$\begin{array}{c}\mathrm{K} \\
\left(\mathrm{mg} / \mathrm{dm}^{3}\right)\end{array}$} & \multirow{2}{*}{$\begin{array}{c}\text { Organic } \\
\text { Matter } \\
(\%)\end{array}$} & \multirow{2}{*}{$\begin{array}{c}\mathrm{Al} \\
\left(\mathrm{cmolc} / \mathrm{dm}^{3}\right)\end{array}$} & \multirow[t]{2}{*}{$\mathrm{pH}$} \\
\hline & Sand & Silt & Clay & & & & & & & & \\
\hline $0-20$ & 78 & 14 & 8 & 1.36 & 2.60 & 0.47 & 32.3 & 136.0 & 1.0 & 0.6 & 4.8 \\
\hline $20-40$ & 79 & 15 & 6 & 1.38 & 2.60 & 0.47 & 33.4 & 84.0 & 0.5 & 0.6 & 5.0 \\
\hline $40-60$ & 75 & 18 & 7 & 1.47 & 2.60 & 0.43 & 17.1 & 60.0 & 0.5 & 1.0 & 5.0 \\
\hline $60-80$ & 74 & 20 & 7 & 1.48 & 2.60 & 0.43 & 11.8 & 60.0 & 0.4 & 1.2 & 4.9 \\
\hline $80-100$ & 68 & 22 & 10 & 1.47 & 2.60 & 0.43 & 5.3 & 64.0 & 0.4 & 0.6 & 5.0 \\
\hline Média & 74.8 & 17.8 & 7.6 & 1.43 & 2.6 & 0.45 & 19.98 & 80.8 & 0.56 & 0.8 & 4.9 \\
\hline
\end{tabular}

The equipment consists of a metal tripod made of steel and it was designed and produced by the Laboratory of Soil Bioengineering of the Federal University of Santa Maria. The portable tripod is adjustable to uneven surfaces, and has been designed to withstand an electric winch with continuous torque and constant displacement. In order to keep the forces applied at an upright position, the steel cable winch went through a metal pulley on the top of the tripod. A load cell with a maximum capacity of $10 \mathrm{kN}$ was coupled to the end of the steel cable and connected to a frequency amplifier for reading and sending the signals to a computer for instantaneous data storage. These data provided the maximum pullout strength $(\mathrm{kN})$ of each plant.

To minimize variations in soil moisture, vertical pullout tests were performed at least 4 days after intense precipitation. The water content in the soil was monitored according to the degree of soil saturation ( $\mathrm{S}=$ volume of water / volume of voids). This approach allowed the majority of tests to be performed under similar soil moisture conditions.

Growth variables from the shoots and the root system were measured at the moment of pullout tests. From the shoots, the number, diameter ( $\mathrm{mm})$ and length $(\mathrm{cm})$ of the shoots were obtained. From the root system, the diameter of the roots at the point of rupture $(\mathrm{mm})$ and the length $(\mathrm{cm})$ of the main roots remaining in the plants after pullout were obtained.

\subsection{Contribution to soil shear strength}

The contribution of the roots to the shear strength, or $\mathrm{Cr}(\mathrm{kPa})$, was estimated using Equation 1 (Wu et al., 2014):

$$
C_{r}=\frac{F_{\max }}{\pi \cdot d \cdot L} * 0.5
$$

in which: $F_{\max }$ is the maximum resistance to pullout $(\mathrm{kN}) ; d$ is the diameter of the cutting $(\mathrm{m})$; and $L$ is the length of the cutting $(\mathrm{m})$. The multiplication by 0.5 is a conservative measure since it assumes that the roots are present only in $50 \%$ of the surface of rupture (Wu et al., 2014).

\subsection{Growth analysis and plant resistance}

Variations in pullout resistance and also from the shoots and root system development were investigated through analysis of variance (ANOVA) and the comparison of means (Tukey test at 5\% of error probability).

All analyzes were performed using MS Excel and the Statistical Analysis System 9.2 software (SAS).

\subsection{Slope stability}

After estimating the contribution of the plants root system to the soil shear strength, stability calculations were made for hypothetical slopes with planar (translational slip) and curved (rotational slip) rupture surfaces. Slope stability was obtained by determining the factor of safety, which indicates the ratio between soil shear strength along a potential rupture surface (resisting forces) and the shear stress acting on this surface (driving forces).

In the case of the slope with planar rupture surface, determination of the plants effect over time on the stability was carried out using Equation 2 (Preti \& Giadrossich, 2009):

$$
F s=\frac{C^{\prime}+C r}{\gamma_{s a t} \cdot z \cdot \cos \beta \cdot \sin \beta}+\frac{\gamma_{s u b} \cdot z \cdot \cos \beta}{\gamma_{s a t} \cdot z \cdot \cos \beta} \cdot \frac{\tan \varphi}{\tan \beta}
$$

which: $F s$, factor of safety; $C^{\prime}$, soil cohesion $(\mathrm{kPa}) ; \mathrm{Cr}$, root contribution to shear strength $(\mathrm{kPa}) ; z$, vertical depth of the slip plane $(\mathrm{m}) ; \beta$, slope angle $\left(^{\circ}\right) ; \varphi$, angle 
of internal friction of the soil $\left({ }^{\circ}\right) ; \gamma_{s u b}$, submerged bulk unit weight of soil $\left(\mathrm{kN} / \mathrm{m}^{3}\right) ; \gamma_{\text {sat }}$, saturated bulk unit weight of soil $\left(\mathrm{kN} / \mathrm{m}^{3}\right)$.

The factors of safety were calculated under the following conditions: saturated bulk unit weight of soil $\gamma_{\text {sat }}=18 \mathrm{kN} / \mathrm{m}^{3}$, water unit weight $\gamma_{w}=9.8 \mathrm{kN} / \mathrm{m}^{3}$, slope angle $\beta=35^{\circ}$, angle of internal friction of the soil $\varphi=27.3^{\circ}$, soil cohesion $C^{\prime}=0, C r=$ root contribution to shear strength $(\mathrm{kPa})$ at $2,4,6,8,10$ and 14 months of plant development. The vertical depth of the slip surface $z(\mathrm{~m})$ was defined as the length of the buried cutting, which is $0.4 \mathrm{~m}$.

In the case of the slope with curved rupture surface, determination of the plants effect on slope stability was carried out using GEOSLOPE software. Morgenstern-Price was the method used for determining the factors of safety. The parameters of resistance and geometric characteristics of the slope were similar to those used for determining slope stability with planar rupture surface. It was assumed that the effect of the plants was homogeneous throughout the entire slope in the different situations.

\section{RESULTS AND DISCUSSION}

\subsection{Plant growth and pullout resistance}

The live cuttings began to sprout three weeks after planting. The lowest survival rate was 75\% (18 live cuttings) and it occurred during winter at 8 months of age. The survival rate in the other periods of growth was greater than $87 \%$ (21 live cuttings).

The pullout resistance of $P$. sellowianus followed the development of the shoots and the root system (Figure 1). These three variables increased linearly until late autumn. In winter the variables had considerable

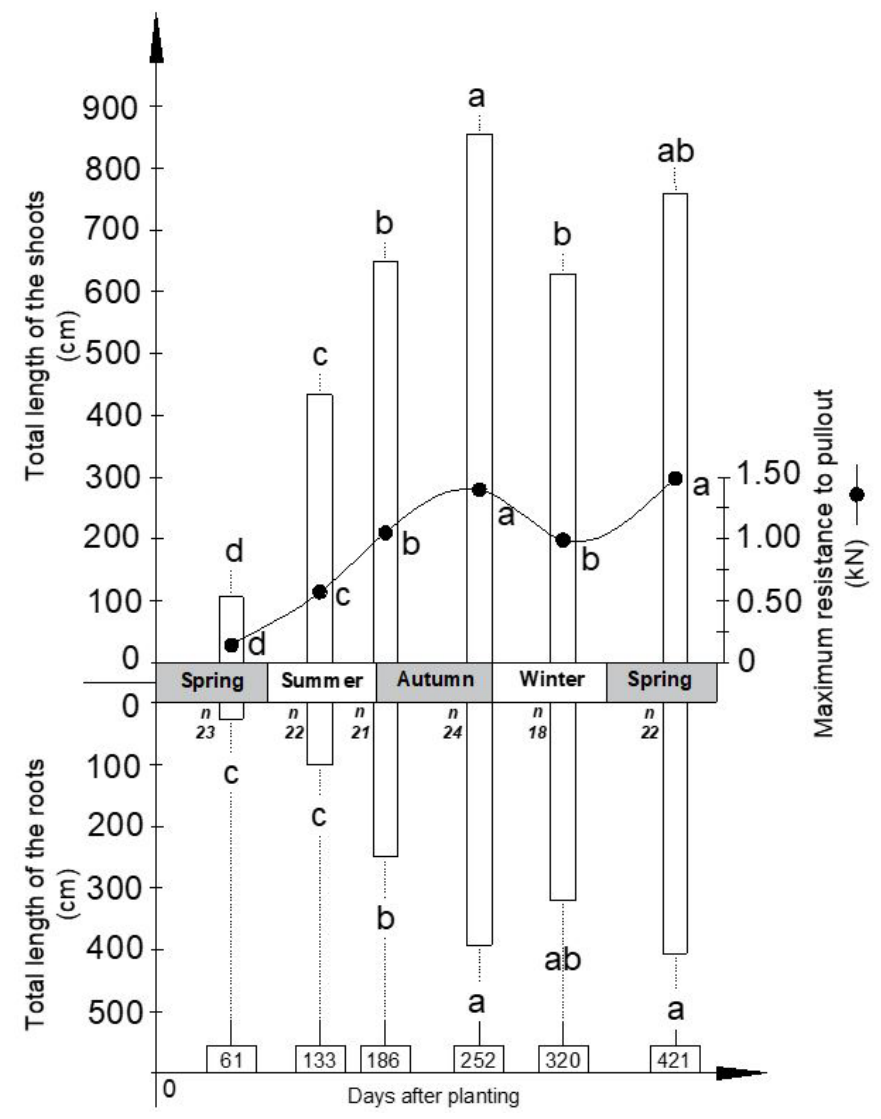

Figure 1. Relationship between the vertical pullout resistance and the total length of shoots and roots of Phyllanthus sellowianus (Klotzsch) Müll.Arg. The data includes plants of 2, 4, 6, 8, 10 and 14 months old. Average values with the same letters are not statistically different from each other according to the Tukey test at $5 \%$ probability of error; $\mathrm{n}$ is the number of plants evaluated in each period. 
reductions in their values due to the intense cold and frequent frosts, being statistically the same as those found in early autumn, almost 5 months before. This drastic decrease resulted from the shoot apex being burnt and from thin root $\operatorname{rot}(<2 \mathrm{~mm})$.

In addition, it may have been influenced by the increase in the amount of water in the soil and consequently a reduction of matric suction effect, since the degree of soil saturation was 100\% (which was not repeated in the other evaluated periods). Growth and resistance variables only increased again with the beginning of spring, at 14 months of age. At this stage, the values were statistically similar to those found at the end of autumn, so that the plants lost about 6 months of development and contribution to soil resistance due to the influence of winter.

The average increment in pullout resistance during the more favorable seasons for plant development (spring, summer and early fall) was approximately $0.20 \mathrm{kN} /$ month, accompanied by mean increases in total length of shoots and roots of 118.4 and $57.1 \mathrm{~cm} / \mathrm{month}$, respectively. In the winter period, the resistance decreased at the rate of $0.18 \mathrm{kN} / \mathrm{month}$, followed by losses in shoot and root length of 100 and $30 \mathrm{~cm} /$ month, respectively. The maximum pullout resistance values, which ranged from 0.028 to $2.170 \mathrm{kN} /$ plant, were similar to those reported in previous studies for different species and propagation forms (Karrenberg et al., 2003; Burylo et al., 2009; Liu et al., 2014).
The plants contribution to soil resistance ranged from $4.5 \mathrm{kPa}$ at 2 months of age to $47.6 \mathrm{kPa}$ at 14 months of age (Figure 2). These values were similar to those found by Wu et al. (2014) in studies with live cuttings of Salix sp. of up to $1 \mathrm{~m}$ in length. The plant contribution rate to resistance during more favorable growth periods was approximately $6.0 \mathrm{kPa} /$ month. In winter, the contribution losses were approximately $5.8 \mathrm{kPa} /$ month, practically equaling the growth gains in the seasons favorable to growth. Figure 2 shows that the winter contribution value $(31.5 \mathrm{kPa})$ was practically the same as that of early fall $(33.4 \mathrm{kPa})$. In the spring resistance increased again, however at a rate of $4.8 \mathrm{kPa} /$ month.

A joint analysis of Figures 1 and 2 shows that the increments in resistance are dependent on both the root system and the shoot growth of the plants. Moreover, the influence of the seasons on growth and resistance is an indication that any interference that modifies the growth rhythm of plants can also indirectly modify soil resistance.

For a conservative assessment, the contribution values of the root system for soil shear strength $(\mathrm{Cr})$ were reduced by half before being used in stability calculations. This reduction assumes that the roots are only present in half of the potential surface rupture of a slope. In addition, the resistance of live cuttings to shear and bending was neglected in order to favor a conservative assessment.

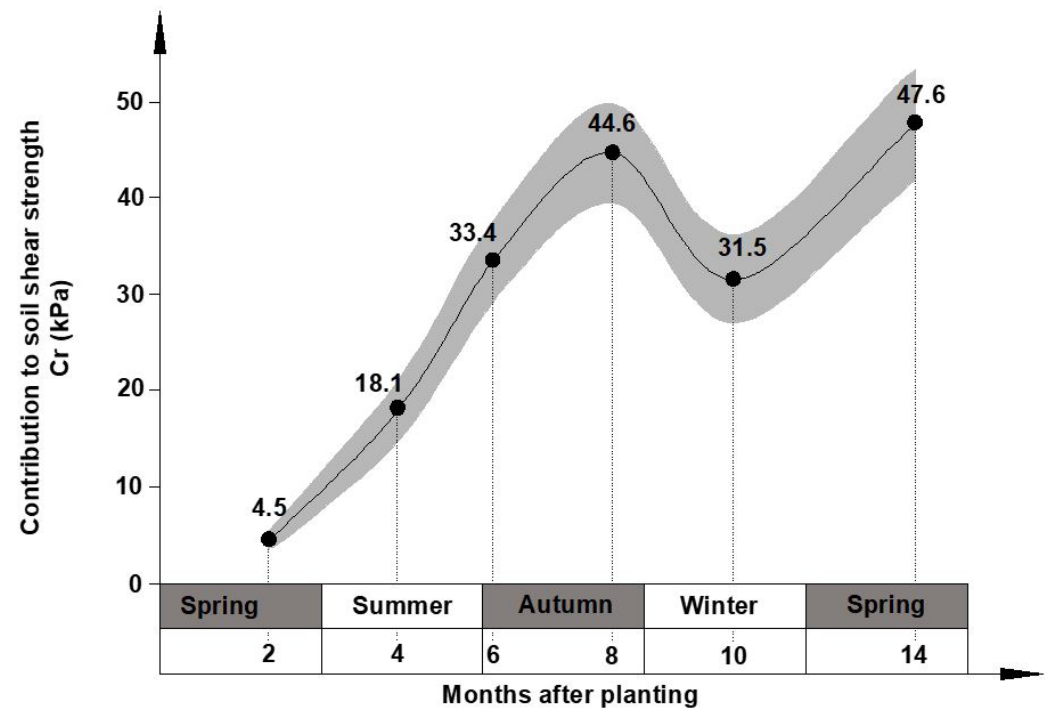

Figure 2. P. sellowianus (Klotzsch) Müll.Arg. live cuttings contribution to soil strength over the course of 14 months of development. The presented values were not multiplied by 0.5 , as suggested by Wu et al. (2014). 
The overload provided by the plants is often considered in slope stability calculations. For P. sellowianus, the overload can be disregarded since the value obtained at 14 months of development (the last period evaluated) was only $1.7 \mathrm{~kg} / \mathrm{m}^{2}$.

The factors of safety for the slope with planar rupture surface followed the increases in $\mathrm{Cr}(\mathrm{kPa})$ (Figure 3). The factor of safety (FoS) for the slope without plants was 0.33 , which represents an unstable condition, since there is no physical meaning for values below 1 (Gerscovich, 2016). In those with plants, the slope started to present FoS of 0.99 at only 2 months, almost reaching the limit equilibrium condition. The slope FoS was already greater than 2 (stable condition) at 4 months of plant development.

FoS values increased at the rate of 0.99 per month in the growth-friendly period. This rate was only possible due to the mechanical contribution of the roots, since there were no effects such as surface protection (shoots), evapotranspiration (moisture depletion) or resistance of live cuttings stem to bending and shear. Even in winter at 10 months of age when the FoS reduced to around 0.86 per month, the slope continued to present a high stability condition ( $F S=4.97)$. Plant growth resumed in the spring (FoS of 0.71 per month) at 14 months, causing the slope to reach its greatest stability during the evaluated period ( $\mathrm{FoS}=7.36)$.

Except for winter, the increase of FoS values according to plant growth always increased. This suggests that the plants' contribution to soil reinforcement both laterally and in depth should continue to progress as long as their growth rate does not decrease.
Both the lateral and vertical roots (pivotal roots) are of extreme importance to guarantee the stability of a slope. Lateral roots act by interconnecting the most superficial layers of the soil (Schwarz et al., 2015), while vertical roots act in depth as anchoring elements, interconnecting the weaker layers of soil with the more resistant ones (Gray \& Leiser, 1982; Gray \& Sotir, 1996; Stokes et al., 2008; Norris et al., 2008). Few plants showed in-depth root development during the evaluated period (about $90 \%$ of the roots occurred at $10 \mathrm{~cm}$ depth). According to Khuder et al. (2007), it is common for plants propagated from live cuttings to have prominent vertical roots after the age of 5. In addition, lateral roots also tend to grow deeper as the plant grows and needs more support.

The factors of safety for slope with curved rupture surface also followed $\mathrm{Cr}$ values, however the differences between slopes with and without plants were less pronounced (Figure 4). The values ranged from 0.95 in slopes without plants to 1.58 in slopes with plants (at 14 months). This difference (0.63) allowed to change the slope condition from unstable to stable. Plant development for six months was sufficient to reach a $\mathrm{Cr}$ of $16.7 \mathrm{kPa}$ and consequently provide the slope with the desired stability ( $\mathrm{FoS}=1.45$ ).

The rate of FoS increase in the most favorable growth period was approximately 0.08 per month, a much lower figure than that found in the same period for the slope with planar rupture (0.99 per month). In winter, the reduction rate in FoS was small, about 0.05 per month. This loss was not enough to impair slope stability.

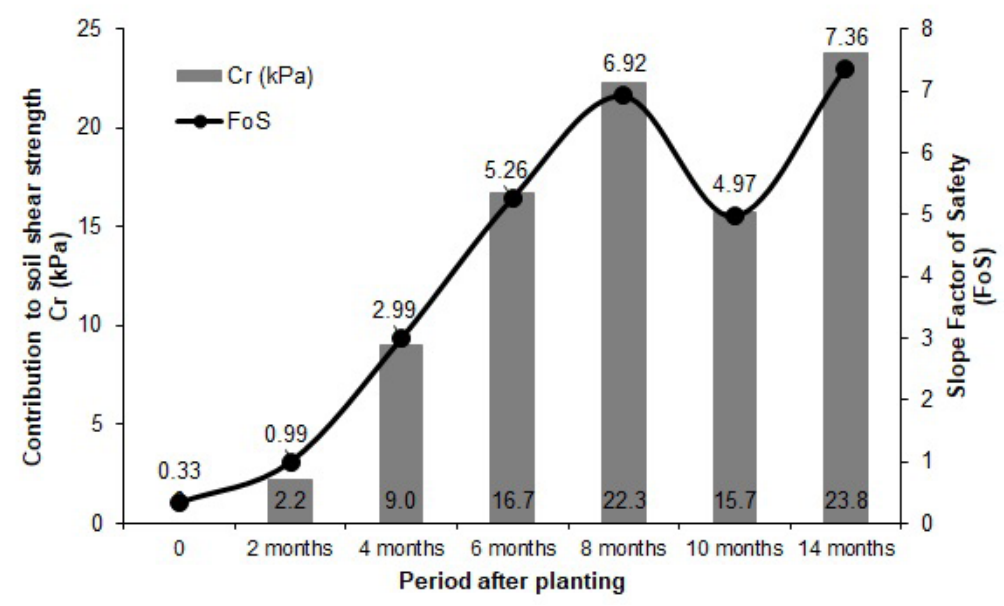

Figure 3. Variations in the factor of safety of a slope with planar rupture surface according to the development of P. sellowianus (Klotzsch) Müll.Arg. live cuttings and their contribution to the soil shear strength. 
The effects of absence and presence of plants (at 14 months) on a slope with curved rupture surface are schematically shown in Figure 5.

In the slope without plants (Figure 5A), it can be observed that the soil loss is imminent, since the FoS is 0.95 (conditionally stable). The average depth of the potential rupture surface is approximately $1.0 \mathrm{~m}$. Hypothetically, if the rupture occurs in an area of $100 \mathrm{~m}^{2}$, soil loss should be $100 \mathrm{~m}^{3}$. In the case when the slope is located on the edge of a watercourse, the loss

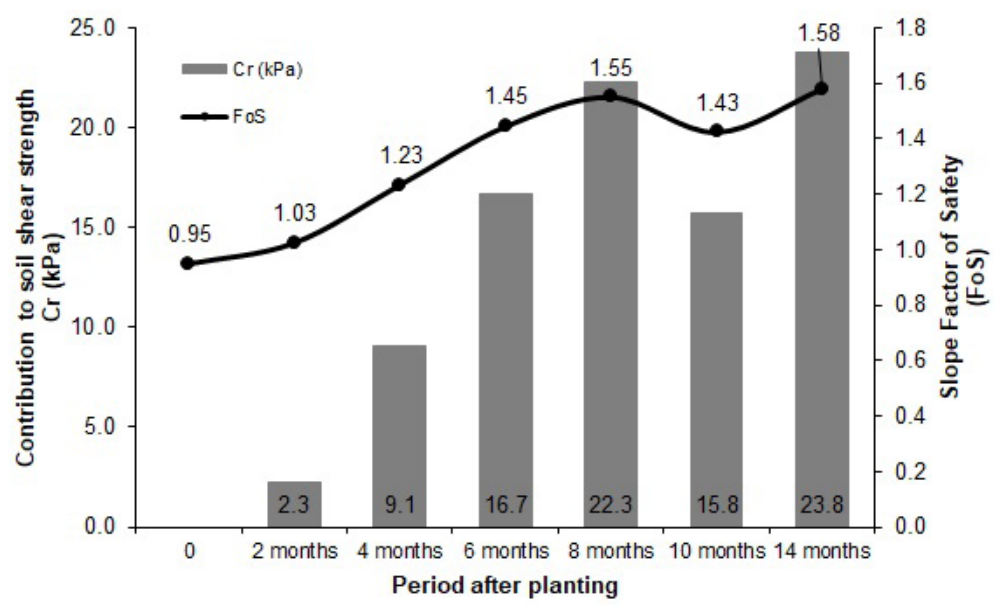

Figure 4. Variations in the factor of safety of a slope with curved rupture surface (with angle of inclination of $35^{\circ}$ ) according to the growth of $P$. sellowianus (Klotzsch) Müll.Arg. live cuttings and their contribution to the soil shear strength.

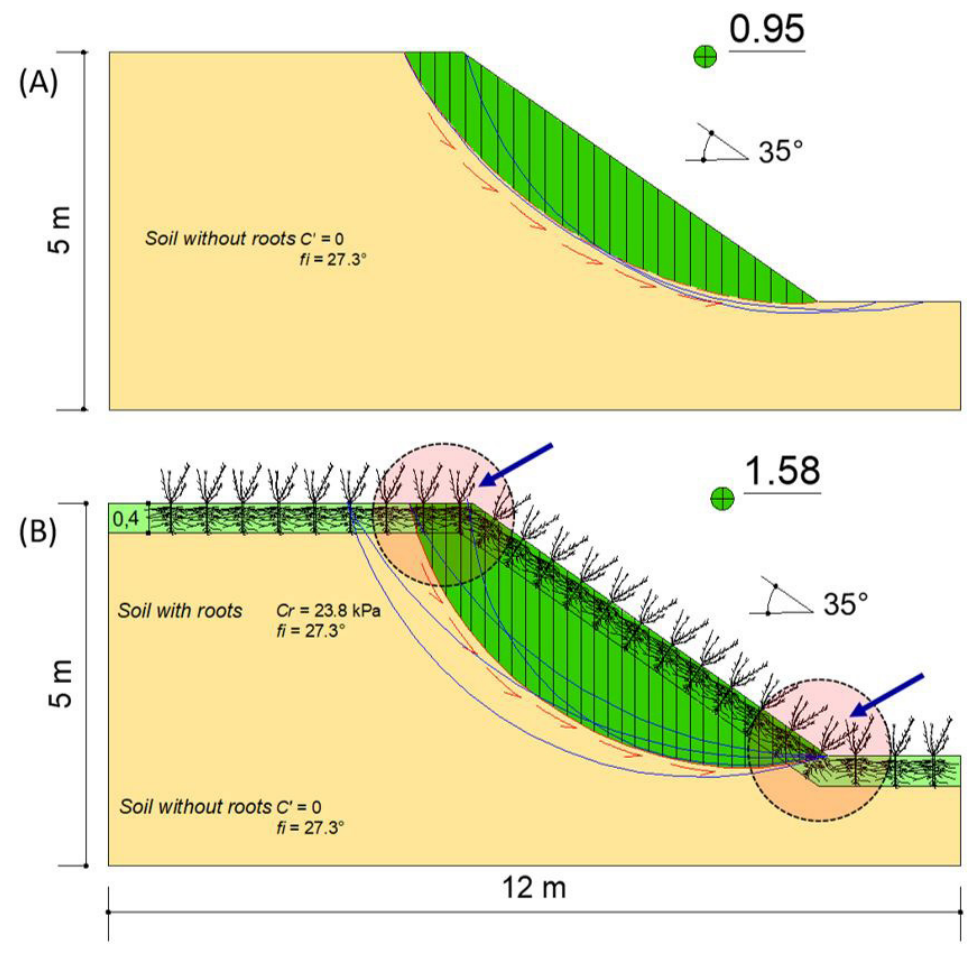

Figure 5. Slope stability analysis with P. sellowianus (Klotzsch) Müll. Arg. live cuttings after 14 months of development (B) and without (A). The red lines indicate the position of the rupture surface with the lowest calculated factor of safety. Blue lines represent potential rupture surfaces with FoS $>1.58$. The arrows indicate the main points of roots contribution to slope stability. 
should be even greater as a function of the flow energy and the saturation overload (in the case of floods with rapid lowering of the water level).

Therefore, in the slope with plants (Figure 5B), we can notice the effect of the $0.4 \mathrm{~m}$ layer of live cuttings and roots on the slope constituted by material without cohesion. The increase of the soil shear strength is verified by the increase in FoS, which is now 1.58 (stable). This is the lowest FoS found for several tested potential rupture surfaces (in this case 30 ). The potential rupture surface was found from the slope axis at $1 \mathrm{~m}$ depth. The effect of the surface protection (represented by $0.4 \mathrm{~m}$ of roots and live cuttings) acted by moving the rupture surface deeper into the slope. This effect was favorable to stability.

The position that the plants occupy in the slope can also influence how they contribute to stabilization. This can be seen in Figure 5B in the highlights at the top and bottom of the slope. The edges are the places where the surface of rupture is at a lower depth, therefore being easier to be reached and overcome by the roots. Plants can only contribute to the stability of a slope if this condition is fulfilled (Wu, 2013).

At the top of the slope (where tensile cracks may occur) the roots provide traction and they hold the soil mass preventing landslides (Schwarz et al., 2010, 2012, 2015). The plants undergo compression at the base of the slope and act as a buttress wall, helping to contain the soil mass (Ali et al., 2013; Schwarz et al., 2015). In the slope axis with curved rupture surface, the surface of rupture depth is always greater and the roots tend to take longer to reach it. This is a temporary limitation (as the roots grow); however, it can be circumvented by performing biotechnical interventions with the use of live cuttings with greater length. In addition to P. sellowianus, species such as Gymnanthes schottiana Müll. Arg. and Salix humboldtiana Willd. also have the capacity to provide live cuttings longer than $1 \mathrm{~m}$.

The homogeneous and dense distribution of roots of the same species tend to reach the same depth in the soil due to their morphological characteristics (Coppin \& Richards, 2007). This feature may not be of interest for soil stabilization, since the maximum depth of the roots reach can establish a preferential surface of rupture. The solution for this condition is to use several species that have root systems with different morphological characteristics and would therefore occupy different layers of soil depths.

\section{CONCLUSIONS}

Slope stability was positively influenced by plant development. The slopes without plants presented the lowest factors of safety and also the most critical conditions of stability. In the case of slope with planar rupture surface, the stability condition was reached just 4 months after planting. For the slope with curved rupture surface, the same condition was reached with plants at 6 months of age.

The general behavior of the relationship between plant development and the factor of safety suggests that stability should increase over time as growth rates do not decrease. In that case, increases in factor of safety values should stagnate when plants reach maturity or begin to compete for water and nutrients. Reductions in factors of safety should only be expected in winter, however at rates that do not compromise slope stability.

\section{SUBMISSION STATUS}

Received: 4 july, 2017

Accepted: 19 jan., 2018

\section{CORRESPONDENCE TO}

\section{Charles Rodrigo Belmonte Maffra}

Universidade Federal de Santa Maria - UFSM, Av. Roraima, 1000, Prédio 44N, CEP 97110-210, Santa Maria, RS, Brasil

e-mail: charles.maffra@gmail.com

\section{REFERENCES}

Ali F, Osman R, Kamil SSSM. The influences of root branching patterns on pullout resistance. EJGE 2013; 18: 3967-3977.

Associação Brasileira de Normas Técnicas - ABNT. NBR 11682: estabilidade de taludes. Rio de Janeiro: ABNT; 2009.

American Society for Testing and Materials - ASTM. ASTM D3080/D3080M: standard method for direct shear test of soils under consolidated drained conditions. West Conshohocken: ASTM; 2011.

Burylo M, Rey F, Roumet C, Buisson E, Dutoit T. Linking plant morphological traits to uprooting resistance in eroded marly lands (Southern Alps, France). Plant and Soil 2009; 324(1-2): 31-42. http://dx.doi.org/10.1007/ s11104-009-9920-5. 
Coppin NJ, Richards IJ. Use of vegetation in civil engineering. 2nd ed. London: Construction Industry Research and Information Association; 2007.

Gerscovich DMS. Estabilidade de taludes. 2. ed. São Paulo: Oficina de Textos; 2016.

Gray DH, Leiser AT. Biotechnical slope protection and erosion control. 1st ed. New York: Van Nostrand Reinhold; 1982.

Gray DH, Sotir RB. Biotechnical and soil bioengineering slope stabilization: a practical guide for erosion control. 1 st ed. New York: Wiley \& Sons; 1996.

Karrenberg S, Blaser S, Kollmann J, Speck T, Edwards PJ. Root anchorage of saplings and cuttings of woody pioneer species in a riparian environment. Functional Ecology 2003; 17(2): 170-177. http://dx.doi.org/10.1046/j.13652435.2003.00709.x.

Khuder H, Stokes A, Danjon F, Gouskou K, Lagane F. Is it possible to manipulate root anchorage in young trees. Plant and Soil 2007; 294(1-2): 87-102. http://dx.doi. org/10.1007/s11104-007-9232-6.

Liu Y, Rauch HP, Zhang J, Yang X, Gao J. Development and soil reinforcement characteristics of five native species planted as cuttings in local area of Beijing. Ecological Engineering 2014; 71: 190-196. http://dx.doi.org/10.1016/j. ecoleng.2014.07.017.

Maffra CRB, Sutili FJ. Metodologia para elaboração de projetos de Engenharia Natural em obras de infraestrutura. Revista Ciência e Ambiente 2017; 46-47: 73-93.

Norris JE, Greenwood JR, Achim A, Gardiner BA, Nicoll BC, Cammeraat E et al. Hazard assessment of vegetated slopes. In: Norris JE, Stokes A, Mickovski SB, Cammeraat E, Van Beek R, Nicoll BC et al., editors. Slope stability and erosion control: ecotechnological solutions. Dordrecht: Springer; 2008. http://dx.doi.org/10.1007/978-1-40206676-4_5.

Preti F, Giadrossich F. Root reinforcement and slope bioengineering stabilization by Spanish Broom (Spartium junceum L.). Hydrology and Earth System Sciences 2009; 13(9): 1713-1726. http://dx.doi.org/10.5194/hess-131713-2009.

Schwarz M, Cohen D, Or D. Spatial characterization of root reinforcement at stand scale: theory and case study.
Geomorphology 2012; 171-172: 190-200. http://dx.doi. org/10.1016/j.geomorph.2012.05.020.

Schwarz M, Preti F, Giadrossich F, Lehmann P, Or D. Quantifying the role of vegetation in slope stability: a case study in Tuscany (Italy). Ecological Engineering 2010; 36(3): 285-291. http://dx.doi.org/10.1016/j.ecoleng.2009.06.014.

Schwarz M, Rist A, Cohen D, Giadrossich F, Egorov P, Büttner $\mathrm{D}$ et al. Root reinforcement of soils under compression. Journal of Geophysical Research. Earth Surface 2015; 120(10): 2103-2120. http://dx.doi.org/10.1002/2015JF003632.

Sousa RS, Maffra CRB, Sutili FJ. Engenharia natural para estabilização de travessia dutoviária: caso 1. Revista Ciência e Ambiente 2017; 46-47: 131-152.

Stokes A, Norris JE, van Beek LPH, Bogaard T, Cammeraat E, Mickovski SB et al. How vegetation reinforces soil on slopes. In: Norris JE, Stokes A, Mickovski SB, Cammeraat E, Van Beek R, Nicoll BC et al., editors. Slope stability and erosion control: ecotechnological solutions. Dordrecht: Springer; 2008. http://dx.doi.org/10.1007/978-1-40206676-4_4.

Waldron LJ. Shear resistance of root-permeated homogeneous and stratified soil. Soil Science Society of America Journal 1977; 41(5): 843-849. http://dx.doi.org/10.2136/sssaj197 $7.03615995004100050005 x$

Wu TH, Kokesh CM, Trenner BR, Fox PJ. Use of live poles for stabilization of a shallow slope failure. Journal of Geotechnical and Geoenvironmental Engineering 2014; 140(10): 1-13. http://dx.doi.org/10.1061/(ASCE)GT.19435606.0001161 .

Wu TH, McKinnell WP 3rd, Swanston DN. Strength of tree roots and landslides on Prince of Wales Island. Alaska Can. Geotech. J. 1979; 16(1): 19-33. http://dx.doi. org/10.1139/t79-003.

$\mathrm{Wu}$ TH. Investigations of landslides on Prince of Wales Island: geotechnical engineering report. 1st ed. Columbus: Department of Civil Engineering; 1976.

$\mathrm{Wu}$ TH. Root reinforcement of soil: review of analytical models, test results, and applications to design. Canadian Geotechnical Journal 2013; 50(3): 259-274. http://dx.doi. org/10.1139/cgj-2012-0160. 